DOI: 10.32089/WBH.PHW.2020.1(271).0009

orcid.org/0000-0002-0059-3462

\title{
Jak nie uprawiać historii historiografii: uwagi na marginesie artykułu Michała Kozłowskiego
}

W numerze 4/2019 „Przeglądu Historyczno-Wojskowego” znalazł się tekst, który w moim przekonaniu nie zasługuje na miano artykułu naukowego: Historycy wojskowości - uczniowie Stanisława Herbsta ${ }^{1}$ autorstwa Michała Kozłowskiego. Autor poruszył w nim zagadnienie wielkiej wagi. Działalność dydaktyczna Stanisława Herbsta niewątpliwie w wielkim stopniu zaważyła na kształcie polskiej historiografii wojskowej po wojnie.

Niestety, ten ważny i potrzebny temat został opracowany w sposób skrajnie nieprofesjonalny. Świadczy to nie tylko o braku kompetencji Autora $\mathrm{w}$ zakresie uprawiania nauki historycznej, lecz także o świadomym łamaniu standardów. Tekst uważam za urągający wymogom naukowości. Ze względu na wyszczególnione niżej powody, także polemika z tekstem Michała Kozłowskiego nie ma - moim zdaniem - sensu.

\section{Zaniechanie przeprowadzenia podstawowej kwerendy archiwalnej}

Stanisław Herbst był promotorem doktoratów przynajmniej w czterech instytucjach: Instytucie Historycznym Uniwersytetu Warszawskiego (IH UW), Instytucie Historii Polskiej Akademii Nauk (IH PAN), Wojskowej Akademii Politycznej im. Feliksa Dzierżyńskiego (WAP), Instytucie Historii Uniwersytetu Jagiellońskiego (IH UJ). Obowiązkiem autora tekstu było sięgnięcie do teczek przewodów doktorskich we wszystkich tych ośrodkach. Jednakże ograniczył się wyłącznie do wojskowego zasobu archiwalnego (akta Wojskowej Akademii Politycznej znajdują się obecnie w Centralnym Archiwum Wojskowym Wojskowego Biura Historycznego - CAW-WBH). W konsekwencji w publikacji aż roi się od luk.

Autor nie wspomina m.in., że uczniem Stanisława Herbsta, który obronił doktorat pod jego kierunkiem na Uniwersytecie Jagiellońskim, był historyk

${ }^{1}$ M. Kozłowski, Historycy wojskowości - uczniowie Stanisława Herbsta, „Przegląd Historyczno-Wojskowy" (PHW) 2019, nr 4 (270), s. 108-155. 
wojskowości Henryk Kotarski. Dysertację pt. „Wojsko polsko-litewskie podczas wojny inflanckiej 1576-1582. Sprawy organizacyjne" obronił w murach krakowskiej uczelni w 1970 r. Była ona także publikowana, choć w pięciu częściach (głównie z powodów cenzuralnych nie mogła ukazać się w formie książkowej), na łamach „Studiów i Materiałów do Historii Wojskowości”2.

Tadeusz Chudoba w tomie Wojsko. Wojskowość. Miasta. Studia poświęcone prof. Stanisławowi Herbstowi ${ }^{3}$ wspomina, że na seminarium Stanisława Herbsta przychodziła grupa doktorantów z Wydziału Architektury Politechniki Warszawskiej. Należałoby więc sprawdzić w Archiwum Politechniki Warszawskiej, czy Herbst nie wypromował tam żadnego doktora. Kozłowski wielokrotnie przywołuje publikację, w której wydrukowano tekst Chudoby, mamy zatem do czynienia nie tyle z niewiedzą, co lekceważeniem.

Kwerendy, zarówno w Archiwum UJ, jak i w Archiwum Politechniki Warszawskiej są bez wątpienia ważną czynnością i szkoda, że Autor nie zechciał ich przeprowadzić. Jednak pominięcie zasobu Archiwum UW w znacznym stopniu zaważa na negatywnej ocenie omawianego tekstu.

\section{Wykorzystywanie szczegółowych danych bez podania podstawy źródłowej}

Mając na uwadze powyższy zarzut o nieprzeprowadzeniu podstawowej dla tego tematu kwerendy archiwalnej, przechodzę do sprawy, która się z tym wiąże. Autor dokonuje prostego podziału uczniów Stanisława Herbsta na tych, którzy napisali doktoraty pod jego kierunkiem na UW (osobno wymienił uczestników seminarium z dziejów kultury i miast), oraz uczestników seminarium $\mathrm{z}$ historii wojskowej. Bez przypisu do jakiegokolwiek źródła ani opracowania przywołuje wszystkie prace napisane na uniwersyteckim seminarium i podaje następujące dane: imię i nazwisko doktoranta, tytuł pracy, datę obrony. Ale skąd to wie? Tego czytelnik się nie dowie. Można przypuszczać, że posiłkował się krążącym swego czasu w internecie zestawieniem pt. „Spis prac doktorskich Wydziału Historycznego 1953-2002”. Jest to bardzo wygodne opracowanie, jednak wymaga weryfikacji. Nie ma ono bowiem autora, nie sygnuje go żadna instytucja ani żadne wydawnictwo. Jeśli jednak Autor tekstu o Herbście zrezygnował z kwerendy w Archiwum UW, uznawszy owo zestawienie za wystarczające, jego obowiązkiem było przywołać to opracowanie w przypisach i bibliografii. Wiele wskazuje na to,

${ }^{2}$ H. Kotarski, Wojsko polsko-litewskie podczas wojny inflanckiej 1576-1582. Sprawy organizacyjne, cz. 1, „Studia i Materiały do Historii Wojskowości” (SMHW) 1970, t. XVI, cz. 2, s. 63-123; cz. 2, SMHW 1971, t. XVII, cz. 1, s. 51-124; cz. 3, t. XVII, cz. 2, s. 81-151; cz. 4, SMHW 1972, t. XVIII, cz. 1, s. 3-92; cz. 5, t. XVIII, cz. 2, s. 43-104.

${ }^{3}$ Wojsko. Wojskowość. Miasta. Studia poświęcone prof. Stanisławowi Herbstowi w stulecie urodzin, red. K. Bobiatyński, P. Gawron, M. Nagielski, Zabrze 2009. 
że informacje zawarte w tekście dotyczącym uczniów Stanisława Herbsta, zamieszczone w omawianej publikacji, pochodzą w większości właśnie $\mathrm{z}$ tego materiału. Takie postępowanie jest zwyczajnie nieuczciwe i niezgodne z oczywistymi zasadami publikacji badań naukowych.

\section{Nierzetelność}

Rzadko który historyk jest również matematykiem. Nieczęsto też się zdarza, by był także polonistą. Niemniej wykształcenie już na poziomie podstawowym przejawia się posiadaniem takich kwalifikacji, jak umiejętność prostych wyliczeń oraz czytania ze zrozumieniem. Autor wymienił w swoim tekście wszystkich uczniów Herbsta, którzy obronili prace doktorskie na UW. Ze wspomnianego „Spisu...” wynika, że było ich $43^{4}$. Jednak na s. 112 omawianego tekstu znajdujemy zdanie: „Od lat pięćdziesiątych do roku akademickiego 1972/1973 w IH UW powstało ponad 50 prac doktorskich". Przypis odsyła nas do artykułu Mirosława Nagielskiego z tomu Wojsko. Wojskowość. Miasta... Na podanej w tymże przypisie s. 38 Nagielski pisze jednak, że ponad 50 prac doktorskich pod kierunkiem Stanisława Herbsta powstało zarówno na UW, jak i w WAP5. Biorąc pod uwagę temat tekstu Kozłowskiego, informacja o liczbie wypromowanych przez Herbsta doktorów jest ważna. Zamiast dokonania prostego obliczenia Autor wolał powołać się na publikację, której nie doczytał bądź nie zrozumiał. W konsekwencji o tak prostej, wydawałoby się, sprawie informuje w sposób nierzetelny.

W związku z niedbalstwem w tekście znajdziemy skądinąd zabawne wpadki. Na s. 109 Autor próbuje określić, czyim uczniem był Stanisław Herbst. Słusznie przypomina, że napisał doktorat pod kierunkiem Oskara Haleckiego. W pokrętny sposób stara się zwrócić uwagę na wpływ Wacława Tokarza na wczesne badania Herbsta: „Ze względu na zainteresowania Herbst był uczniem Wacława Tokarza, choć uczęszczał również na seminarium Marcelego Handelsmana”. Skoro już Kozłowski postanowił zlekceważyć zasób Archiwum UW, to przynajmniej mógł sięgnąć do znakomitej biografii Tokarza autorstwa Piotra Bilińskiego, w której jest mowa o uczestnictwie Herbsta w seminarium autora Insurekcji warszawskiej, a także o tym, iż Tokarz uważał Herbsta za swojego ucznia (P. Biliński, Wacław Tokarz 1873-1937. Historyk walk o niepodległość, Kraków 2018, s. 138-139)6.

${ }^{4}$ Dokładnie w tej liczbie Autor wymienił doktorantów Herbsta na UW.

${ }^{5}$ M. Nagielski, Stanisław Herbst jako dydaktyk i wychowawca wielu pokoleń historyków wojskowości [w:] Wojsko. Wojskowość. Miasta..., s. 38.

${ }^{6}$ Warto w tym miejscu przypomnieć, że Kozłowski był Autorem zawierającej szereg błędów merytorycznych recenzji książki Piotra Bilińskiego; zob. M. Kozłowski [Rec.], P. Biliński, Wacław Tokarz 1873-1937. Historyk walk o niepodległość, Kraków 2018, PHW 2019, nr 1 (267), s. 217-221. 
Biliński wskazał także konkretnie, że pracę magisterską Herbst napisał pod kierunkiem Henryka Mościckiego, a promotorem doktoratu był Halecki. Natomiast Kozłowski przywołuje w przypisach wybrane opinie historyków na temat tego czyim uczniem był Herbst i poucza Marię Wierzbicką, autorkę biogramu Herbsta w Słowniku historyków polskich w przypisie nr 5: „Dość często Herbst jest uważany błędnie za ucznia Haleckiego [podkr. T. S.]: M. Wierzbicka, Herbst Stanisław [w:] Słownik historyków polskich, red. M. Prosińska-Jackl, Warszawa 1994, s. 181”. Otwieramy więc przywołaną publikację i czytamy: „Po studiach z zakresu historii i historii sztuki na UW (uczeń m.in. W. Tokarza) i doktoracie (1931 pod kier. O. Haleckiego [podkr. T. S.]) pracował m.in. w Min. WRiOP)". Warto więc uzmysłowić Autorowi, że zazwyczaj posiada się jednego promotora pracy magisterskiej lub doktorskiej. Bywają wprawdzie przypadki, że promotorów jest dwóch, ale dotyczy to głównie prac, które powstały w ramach współpracy międzynarodowej. Natomiast w sytuacji, gdy promotor jest jeden, nie można wykluczyć, że nauczycieli było więcej - wielu studentów uczęszcza na więcej niż jedno seminarium.

\section{Oszustwo}

Omawiana publikacja jest w istocie wyliczanką uczniów Herbsta, którzy napisali prace doktorskie z zakresu historii wojskowości. Samymi doktoratami Autor się nie zajmuje. Nie zadaje sobie pytania o program badawczy, realizowany przez Herbsta wśród oficerów przygotowujących doktoraty w Wojskowej Akademii Politycznej ani doktorantów Uniwersytetu Warszawskiego. Przytacza tytuły w otoczeniu przypadkowych (najłatwiej dostępnych) informacji biograficznych. Podczas gdy takie zestawienie dysertacji obronionych na UW było zadaniem banalnym, przecież można było skorzystać z przywołanego powyżej „Spisu...”, tak z doktorantami z WAP jest już trudniej. I tak na s. 134-135 znajdujemy tabelę, w której wyliczono uczniów Herbsta z WAP. Następnie każdego z osobna Autor omawia w kilku- lub kilkunastozdaniowych biogramach. Na s. 138 czytamy: „W 1962 r. doktorat pod kierunkiem Herbsta uzyskał z kolei Józef Chęciński”. Autor w przypisie do tej informacji odsyła nas do dwóch teczek: teczki akt personalnych Chęcińskiego (w tym materiale nie znajdziemy żadnej informacji na temat jego doktoratu) oraz akt przewodu doktorskiego. Po zapoznaniu się z przywołanymi przez Kozłowskiego aktami przewodu doktorskiego wypada mi poinformować zarówno Autora omawianego tekstu, jak i czytelników, że Chęciński doktoratu u Herbsta nie obronił7. Z teczki, na którą powołuje

${ }^{7}$ Centralne Archiwum Wojskowe Wojskowego Biura Historycznego (dalej: CAW-WBH), Wojskowa Akademia Polityczna (dalej: WAP), sygn. 172.1.48, Akta przewodu doktorskiego. Chęciński Józef, k. 46. 
się Kozłowski, jasno wynika, że do obrony nie doszło. Znajdziemy w niej protokół z posiedzenia Rady Naukowej WAP z dnia 24 czerwca 1963 r. w sprawie przewodu płk. mgr. Józefa Chęcińskiego, informujący, że odbyło się głosowanie w sprawie przyjęcia jego pracy doktorskiej: 3 głosy za, 1 przeciw, 5 wstrzymujących się. Tak więc Rada Naukowa WAP nie przyjęła rozprawy mgr. Chęcińskiego. Autor przywołuje te akta, pisząc jednocześnie, że Chęciński został doktorem w $1962 \mathrm{r}$.

Z powyższych powodów także kwerenda Autora w Centralnym Archiwum Wojskowym Wojskowego Biura Historycznego budzi wątpliwości.

Autor przywołał jednak konkretne dane dotyczące pracy doktorskiej Chęcińskiego. Jeżeli zignorował wspomniane akta przewodu doktorskiego, to może wykorzystał inne źródło?

W 1987 r. Pielesiak obronił pracę magisterską pt. „Profesor Stanisław Herbst jako szef Katedry Historii Wojskowej w latach 1957-1968”, napisaną pod kierunkiem Mieczysława Wieczorka, która wprawdzie nie ukazała się drukiem, ale znajduje się w CAW-WBH ${ }^{8}$. Praca ta ma wiele walorów - jest nie tylko interesującym opracowaniem, lecz także ma pewne cechy źródła historycznego (Ireneusz Pielesiak m.in. przywołuje zebrane przez siebie relacje uczniów Stanisława Herbsta, którzy od wielu lat nie żyją). Pomylił się jednak: w zestawieniu prac doktorskich, zamieszczonym na s. 80-81 maszynopisu, wymienia pracę Józefa Chęcińskiego jako obronioną w 1962 r.

Z publikacji Kozłowskiego dowiadujemy się, że praca Pielesiaka jest mu znana (zob. przypisy nr 79, 88, 91, 116, 118). Najwyraźniej postanowił żerować na niewydanym opracowaniu i powielił także jego błędy. Publikowanie cudzych ustaleń (w tym wypadku błędnych) bez odnoszenia się w przypisie do źródła ani zasygnalizowania go w żaden inny sposób, bywa nazywane kradzieżą intelektualną. Odkładając jednak na bok moralną ocenę postępowania Autora, w następstwie jest to wprowadzanie w błąd czytelnika, powodujące cofnięcie stanu badań. Jest to całkowite zaprzeczenie pracy naukowej.

$\mathrm{Na}$ marginesie należy dodać, że najwyraźniej w związku z zasugerowaniem się pracą Pielesiaka i zaniechaniem wnikliwej kwerendy w materiałach WAP Autor tekstu nie uwzględnił dwóch uczniów Herbsta. Pielesiak w tytule swojej pracy określił cezurę swoich badań (1957-1968). Po 1968 r. Herbst nie był już pracownikiem WAP, jednak wypromował tam dwóch doktorów, „przejętych” po zmarłym w 1970 r. Januszu Wolińskim: byli to Edward Barszcz (ur. 1921 - zm. 2011; napisał pracę pt. „Sprawa polska w Rosji od obalenia caratu do zwycięstwa Wielkiej Socjalistycznej Rewolucji

${ }^{8}$ Zob. CAW-WBH, WAP, sygn. 172.1.2141, Ireneusz Pielesiak, „Profesor Stanisław Herbst jako szef Katedry Historii Wojskowej w latach 1957-1968”, Warszawa 1987. 
Październikowej"9) i Mieczysław Jaworski (ur. 1929 - zm. 1996) ${ }^{10}$. Drugi z nich w książkowym wydaniu swojego doktoratu pt. Na piastowskim szlaku. Działalność Ministerstwa Ziem Odzyskanych w latach 1945-1948 (Warszawa 1973) napisał: „Pragnę także serdecznie podziękować prof. drowi Stanisławowi Herbstowi za przejęcie roli promotora i opiekuna [podkr. T. S.]” (s. 12).

\section{Niewiedza i arogancja}

Ambicją Kozłowskiego było przedstawienie uczniów Stanisława Herbsta. Jak już wspomniałem, gros pracy stanowią zdawkowe i nierówne pod względem objętościowym i jakościowym biogramy. Ze względu na wyżej wykazane nieuczciwe praktyki Autora trudno orzec (bez weryfikowania przypisu po przypisie), na ile zawarte w biogramach informacje zostały wywiedzione z podanych źródeł i opracowań. Forma wywodów pozwala sądzić, że biogramy są nieco pełniejsze w sytuacji, gdy o danych postaciach powstały już jakieś łatwo dostępne opracowania (nekrologi, artykuły wspomnieniowe). Problem polega jednak na tym, że Autor jedynie informuje o zainteresowaniach uczniów Stanisława Herbsta poprzez przywołanie tytułów prac (widniejących przecież w elektronicznym katalogu Biblioteki Narodowej), a rezygnuje $\mathrm{z}$ charakteryzowania ich dorobku, a gdy już tego próbuje (nieudolnie) dokonać, kompromituje się - widać bowiem, że i dorobek bohaterów, i realia epoki, w której prace składające się nań powstały, są mu zupełnie obce.

Jestem jak najdalszy od afirmowania twórczości Bogdana Hillebrandta, który napisał pracę doktorską pod kierunkiem Herbsta. Kozłowski słusznie klasyfikuje go jako historyka związanego z ośrodkami działającymi w ramach Komitetu Centralnego Polskiej Zjednoczonej Partii Robotniczej. Na s. 126-127 wymienia jego publikacje dotyczące historii wojskowej, w tym np. pracę Konspiracyjne organizacje młodzieżowe w Polsce 1939-1945 (Warszawa 1973). Autor jednak charakteryzuje dorobek Hillebrandta jednym zdaniem: „Jak większość prac historyków związanych z WSNS przy KC PZPR jego dorobek jest zdezaktualizowany i ma głównie wymiar propagandowy" (s. 127). Tego rodzaju sformułowanie dowodzi nie tylko arogancji, lecz także świadczy o tym, że Autor nie zna dorobku tzw. historyków partyjnych. Wiele prac, które powstały w tym kręgu, do dziś, jest uznawanych za wartościowe ze względu na zawartą w nich faktografię. Lekturę tych publikacji utrudnia nierzadko specyficzna stylistyka oraz przewartościowania na poziomie interpretacji. Jeżeli jednak Kozłowski zechciałby zajrzeć np. do pracy Piotra Gontarczyka pt. Polska Partia Robotnicza: droga do władzy 1941-1944

\footnotetext{
${ }^{9}$ Zob. CAW-WBH, WAP, sygn. 172.1.110, Akta przewodu doktorskiego. Edward Barszcz.

${ }^{10}$ Zob. CAW-WBH, WAP, sygn. 172.1.128, Akta przewodu doktorskiego. Mieczysław Jaworski.
} 
(Warszawa 2003), przekona się, że jej Autor wielokrotnie wykorzystywał literaturę partyjnej proweniencji. Robił to jednak - jak na rzetelnego i uczciwego historyka przystało - krytycznie. Efektem takiego postępowania jest wyżej wymieniona książka, której rekomendować chyba nie muszę.

Jako historyka "partyjnego" Kozłowski przedstawia także Andrzeja Janowskiego (s. 127). Jednak jego miejsce zatrudnienia przysłoniło Autorowi wszystko inne. Przypomina wprawdzie AK-owską przeszłość Janowskiego, a także informuje nas - zgodnie z prawdą - że tytuł jego doktoratu brzmiał: „Okręg stołeczny Stronnictwa Narodowego 1939-1944”. Fragment mu przestawiony kwituje zaś następująco: „Zajmował się dziejami ruchu robotniczego i historią najnowszą. Jego dorobek ogranicza się jedynie do informatorów o zasobie ZHP i Centralnego Archiwum KC PZPR”. Pomijam fakt, że historią ruchu robotniczego Janowski się nie zajmował. Kozłowski nie dostrzegł jednak ważnej części jego dorobku: w 1970 r. ukazała się obszerna dwutomowa praca pt. Okupacja i ruch oporu w dzienniku Hansa Franka 1939-1945 ${ }^{11}$, przygotowana pod kierunkiem Stanisława Płoskiego - Andrzej Janowski był jedną z osób, która opracowywała to wydawnictwo; w 1989 r., w nr. 2 „Kroniki Warszawy” ukazał się bardzo ważny artykuł Janowskiego poświęcony Januszowi Wolińskiemu; Janowski brał też udział w opracowaniu źródłowego wydawnictwa Ludność cywilna w powstaniu warszawskim, t. 2, red. C. Madajczyk, (Warszawa 1972). Może to dla Kozłowskiego za mało.

Należy jednak zauważyć, że Autor tekstu nie zna realiów epoki. W okresie PRL opublikowanie prac naukowych dotyczących Stronnictwa Narodowego graniczyło z niemożliwością. Ważnym przykładem są prace Jerzego Janusza Tereja, który „wstrzelił się” w początek lat siedemdziesiątych - okres pewnej odwilży. Ukazała się wtedy pewna liczba prac wykraczających poza dotychczasowe ograniczenia, ale większość z nich dość szybko została wycofana $\mathrm{z}$ obiegu księgarskiego i bibliotecznego ${ }^{12}$. Autor nie wspomina, że Janowskiemu udało się wówczas także fragment swoich badań (jeszcze przed obroną pracy doktorskiej) opublikować (A. Janowski, Okręg stołeczny Stronnictwa Narodowego. Dzieje Organizacji (1939-1944) [w:] Warszawa lat wojny i okupacji, z. 2, pod red. K. Dunin-Wąsowicza, J. Kaźmierskiej, H. Winnickiej, Warszawa 1972, s. 167-211, /=„Studia Warszawskie”, t. X/). Po 1973 r. przez kilka lat nie miał możliwości wydania swojej pracy doktorskiej. Janowski był także orędownikiem utworzenia Muzeum Powstania Warszawskiego,

${ }^{11}$ Okupacja i ruch oporu $w$ dzienniku Hansa Franka 1939-1945, t. 1-2, wybór i oprac. pod kier. S. Płoskiego: L. Dobroszycki, A. Janowski et al., Warszawa 1970.

${ }^{12}$ Zob. m.in. L. Moczulski, Wojna polska 1939, Poznań 1972; M. Turlejska, Zapis pierwszej dekady, Warszawa 1972; A. Czubiński, Kraj Rad. Lata zmagań i zwycięstw, Warszawa 1973; A. B. Szcześniak, W. Szota, Droga do nikąd: działalność organizacji ukraińskich nacjonalistów i jej likwidacja w Polsce, Warszawa 1973. 
będąc jego kierownikiem w czasach, gdy placówka była oddziałem Muzeum Historycznego m. st. Warszawy (pełnił tę funkcję w latach 1986-1994) ${ }^{13}$.

Istotną informacją w kontekście drogi badawczej Janowskiego - o czym Autor nie wspomina - jest fakt, że wprawdzie Herbst był promotorem jego dysertacji doktorskiej, jednak pracę nad tym tematem Janowski rozpoczął pod kierunkiem Stanisława Płoskiego (zmarłego w 1966 r.) ${ }^{14}$.

W przypadku Hillebrandta Autor podaje informacje na temat jego habilitacji (temat, rok, miejsce), nie podaje jednak źródła swoich ustaleń, do czego czytelnik po kilku stronach lektury może być już przyzwyczajony. Informacji o habilitacji brakuje z kolei w biogramie Władysława Ważniewskiego, także omawianego jako ucznia Herbsta zarówno w biogramie (s. 127-128), jak i w zestawieniu w tabelce (s. 115). Odesłać należy więc Autora do Archiwum Akt Nowych w którym znajdują się akta KC PZPR, w tym zespół akt szkół partyjnych. Tam uzyskałby informacje na temat kariery naukowej Władysława Ważniewskiego. Habilitował się on na postawie rozprawy Na przedpolach stolicy 1939-1945 (Warszawa 1974) w roku $1975^{15}$.

W gąszczu licznych nieporozumień znalazł się też biogram Czesława Blocha (s. 128-129), historyka związanego z Katolickim Uniwersytetem Lubelskim. Autor napisał, przywołując książkę Macieja Sobieraja pt. Między oporem a lojalnością. Działania SB wobec KUL na przykładzie rozpracowania prof. Jerzego Kłoczowskiego (Lublin 2015), iż: „Tajemniczym aspektem życia Blocha jest to, że był tajnym współpracownikiem bezpieki o pseudonimie «Pedagog»". Następnie zaś dodaje, powołując się na akta Instytutu Pamięci Narodowej, że: „Dodatkowo ustaliłem, że był też podporucznikiem Korpusu Bezpieczeństwa Wewnętrznego" (s. 128). W takim brzmieniu oba te sądy mają charakter insynuacyjny. Jeżeli rzeczywiście Autor miał w rękach świetne opracowanie Sobieraja, to powinien wiedzieć, że od 2015 r. sprawa tajemnicza nie jest. Relacje Blocha ze Służbą Bezpieczeństwa zostały przez Sobieraja opisane. Dodajmy też, że formalna współpraca trwała bardzo krótko, bo dotyczyła lat 1962-1963 (bo z tekstu Kozłowskiego nie dowiadujemy się, czy trwało to rok, pięć lat czy przez okres całej PRL). Warto zwrócić uwagę, że istotne są lata służby Blocha w Korpusie Bezpieczeństwa Wewnętrznego. Kozłowski nie tylko nie napisał, kiedy miała miejsce, lecz także nie wspomina o szalenie istotnym kontekście: Czesław Bloch w $1941 \mathrm{r}$. został wywieziony na Syberię, skąd w 1946 r. powrócił najpewniej w ramach

${ }^{13}$ J. Durko, Muzeum Warszawy i jego wspótpracownicy w mojej pamięci 1951-2003, Warszawa 2008, s. 210.

${ }^{14}$ Archiwum Akt Nowych (dalej: AAN), Zakład Historii Partii przy KC PZPR, sygn. XXII-598, Akta Andrzeja Janowskiego.

${ }^{15}$ AAN, Archiwum Szkół Partyjnych, sygn. 490-K/5/828, Akta Władysława Ważniewskiego, b.p. 
akcji repatriacyjnej. Fakt ten determinował późniejsze losy historyka. Nieuwzględnianie takich niuansów świadczy o lekceważeniu badanej materii, a także - jak w przypadku omawiania losów Janowskiego - o nieznajomości tła historycznego.

Środowisko uczniów Stanisława Herbsta w murach Wojskowej Akademii Politycznej jest bardzo ciekawe i mało znane. Historycy w mundurach stanowią grupę dość hermetyczną i działającą nieco w oderwaniu od akademickiego środowiska historycznego. Gdy jednak przychodzi do omówienia dorobków i karier mniej znanych uczniów Herbsta z WAP, Kozłowski ogranicza się niemal wyłącznie do przywołania informacji z teczek akt personalnych z CAW-WBH i kilku tytułów prac, które możemy znaleźć, wpisując nazwisko autora do elektronicznego katalogu Biblioteki Narodowej. I tak pozbawione podstawowych informacji są biogramy m.in. Juliana Bugajskiego (Autor nie wspomina, że Bugajski po zwolnieniu z wojska pracował w Naczelnej Dyrekcji Archiwów Państwowych ${ }^{16}$, nie przywołuje jego istotnych publikacji w „Roczniku Warszawskim” czy „Archeionie”, a także nie zechciał ustalić daty jego śmierci - 2002 r.) oraz Ireneusza Bujniewicza (Autor przepisał jedynie tytuł doktoratu, nie informuje o jego publikacjach, dotyczących dziejów kolejnictwa ${ }^{18}$, które do dziś zachowują ogromną wartość, a cała praca została opublikowana zaledwie kilka lat temu ${ }^{19}$, nie odnotowuje też daty śmierci - 2002 r.).

\section{Publikacja, w której o nic nie chodzi...}

$\mathrm{Na}$ koniec wypada zwrócić uwagę na koncepcję tekstu, a właściwie na jej brak. Autor nie stawia sobie żadnego celu, nie zadaje pytań (na które szukałby dalej odpowiedzi), toteż nie dochodzi do żadnych wniosków. Trudno mówić o jakiejkolwiek metodologii, a podejmowane próby samodzielnych rozważań w omawianej publikacji są całkowicie jałowe. Na początku tekstu wprowadza pojęcie „szkoły historycznej”, szpikuje tekst odniesieniami do literatury charakteryzującej to zjawisko (zob. przyp. 9 i 10, s. 110), jednak

${ }^{16}$ Nie przeszkadza to Autorowi gdzie indziej powoływać się na publikację, w której pojawia się informacja o pracy Bugajskiego w NDAP (zob. T. P. Rutkowski, Historiografia i historycy w PRL. Szkice, Warszawa 2019, s. 253).

${ }^{17}$ Zob. J. Bugajski, Warszawa w wojskowej twórczości Jana Blocha, „Rocznik Warszawski” 1972, s. 205-216; idem, „Galicyjskie” akta c.k. Ministerstwa Kolei i ich opracowanie, „Archeion" 1974, t. 60, s. 177-193.

${ }^{18}$ I. Bujniewicz, Kształtowanie jednolitego systemu kolejowego w Polsce w latach międzywojennych, „Kwartalnik Historii Kultury Materialnej” 1968, z. 3, s. 517-538.

${ }^{19}$ Idem, Kolejnictwo w przygotowaniach obronnych Polski w latach 1935-1939 [w:] Kolejnictwo w polskich przygotowaniach obronnych i kampanii wrześniowej, t. 1, red. A. Wesołowski, N. Bujniewicz, Warszawa 2011, s. 19-138. 
nie wywodzi na podstawie tych lektur żadnej własnej propozycji na temat szkoły Stanisława Herbsta. Przytaczanie tych pozycji jest w wykonaniu Kozłowskiego jedynie symulacją erudycji. W ostatnim akapicie tekstu (s. 149) bez zastrzeżeń posługuje się jednak terminem „szkoła Herbsta”.

Wnioski, czy też podsumowanie - jeśli tak nazwać ostatnie trzy akapity tekstu (s. 146-149) - są kuriozalne. Otrzymujemy jakiś luźny potok stwierdzeń, będących jakby zapisem strumienia świadomości, np.: „Bez wątpienia sytuacja historyków, którzy wyszli z seminarium Herbsta, nie była łatwa i to nie tylko przez wzgląd na trudności w wydawaniu swych prac naukowych czy też problemy natury materialnej. Na przebieg osobistych karier uczniów w znaczniej mierze miały wpływ ich własny światopogląd oraz postawa polityczna. W badanej grupie uderza niewielka liczba kobiet. Jedyny raz, kiedy w większości uczniowie Herbsta zostali zaangażowani do prac naukowych, to były prace nad «Polskim Słownikiem Biograficznym». Seminarzyści Herbsta starali się syntetyzować i łączyć w spójny światopogląd wiele pojawiających się inspiracji. Każdy z wymienionych historyków wykazywał się odrębnym zdaniem na temat odpowiedniego postępowania badawczego. Żaden z nich nie miał też większych ambicji metodologicznych. To, co ich łączyło, to problematyka obiektywizmu poznania historycznego. Nie potrafili również wytworzyć zdecydowanego i wspólnego stanowiska” (s. 147-148).

Publikacja Kozłowskiego niewiele wnosi do stanu wiedzy. Jeżeli ma się zaliczać do dziedziny, jaką jest historia historiografii, to - w moim przekonaniu - jest to dobry przykład ilustrujący przyszłym badaczom, jak historii historiografii uprawiać nie należy. Tekst ten jest bowiem znakomitym wzorcem nie tylko braku podstawowej wiedzy w zakresie dziejów historiografii wojskowej, lecz także dowodzi całkowitej nieumiejętności jego Autora posługiwania się narzędziami badań historycznych. Smutno zaskakuje jedynie, że zamiast pogłębić swoją wiedzę przed przystąpieniem do pisania tekstu, wybrał drogę przeczącą dobrym obyczajom, a nierzadko zakrawającą na oszustwo.

Tomasz Siewierski (Instytut Historii Nauki Polskiej Akademii Nauk) 